\title{
Isolated mammary cysticercosis
}

\author{
Ajay Kumar Pal, Anand Kumar Mishra, Sandeep Tewari, Ravi Kumar
}

Department of General Surgery, King George's Medical University, Lucknow, Uttar Pradesh, India

\section{Correspondence to} Dr Ajay Kumar Pal, akpal.jnmc@yahoo.com

Accepted 5 September 2015

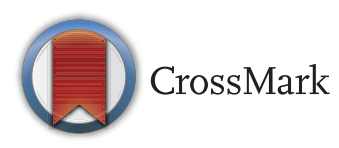

To cite: Pal AK, Mishra AK, Tewari S, et al. BMJ Case Rep Published online: [please include Day Month Year] doi:10.1136/bcr-2015211336

\section{DESCRIPTION}

A 35-year-old woman presented to the surgical outpatient clinic with a 6-month history of a lump in the right breast. There was no history of breast pain, cyclical lumpiness, axillary lump or nipple discharge. There was no medical history, family history or social history of significance. On examination, the patient had a $2 \times 2 \mathrm{~cm}$ firm, non-tender, mobile lump in the upper and outer quadrant of the right breast, with normal overlying skin. Nipple areola complex and axillary examination were normal. Opposite breast, axilla and supraclavicular examination was normal. A mammogram (figure 1) and ultrasonography (figure 2) of the right breast were performed to delineate the underlying characteristics of the lump. The findings were suggestive of cysticercosis of the breast and the patient was treated with albendazole $400 \mathrm{mg}$ twice daily for 15 days. She responded favourably, with the lump decreasing to $1 \times 1 \mathrm{~cm}$. Chest X-ray, ultrason-

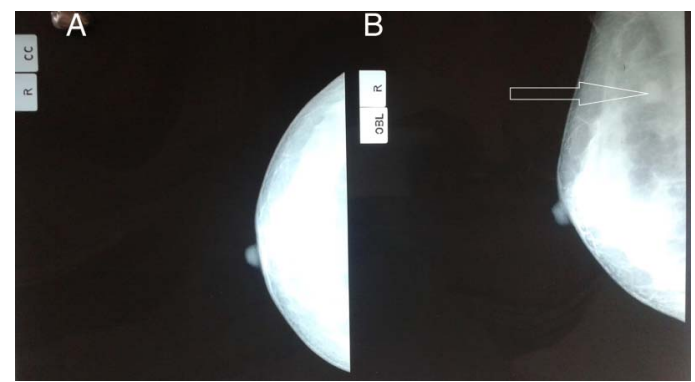

Figure 1 Mammogram of right breast with craniocaudal (A) and mediolateral oblique (B) views and arrow (B) showing radiopaque area surrounded by radiolucent area in upper and outer quadrant. ography of the abdomen and non-contrast CT of the head were carried out to exclude cysticercosis in those areas. All the above investigations were normal. Fine-needle aspiration cytology (FNAC) was inconclusive. Cysticercosis of the breast may mimic a fibroadenoma, ${ }^{1}$ or a breast malignancy. ${ }^{2}$

\section{Learning points}

India is an endemic zone for cysticercosis, and mammary cysticercosis can present in young women with a breast lump.

- Although operator dependent, ultrasonography can be useful for the diagnosis of mammary cysticercosis.

- Conservative medical management can initially be given for small and or asymptomatic lesions.

Contributors AKP drafted the manuscript. AKM was responsible for the concept and design of the manuscript. ST critically revised the manuscript. RK gave final approval of the version submitted.

Competing interests None declared.

Patient consent Obtained.

Provenance and peer review Not commissioned; externally peer reviewed.

\section{REFERENCES}

1 Karthikeyan TM, Manimaran D, Mrinalini VR. Cysticercus of the breast which mimicked a fibroadenoma: a rare case report. J Clin Diagn Res 2012;6:1555-6.

2 Bhattacharjee HK, Ramman TR, Argarwal L, et al. Isolated cysticercosis of the breast masquerading as a breast tumour: report of a case and review of literature. Ann Trop Med Parasitol 2011;105:455-61.

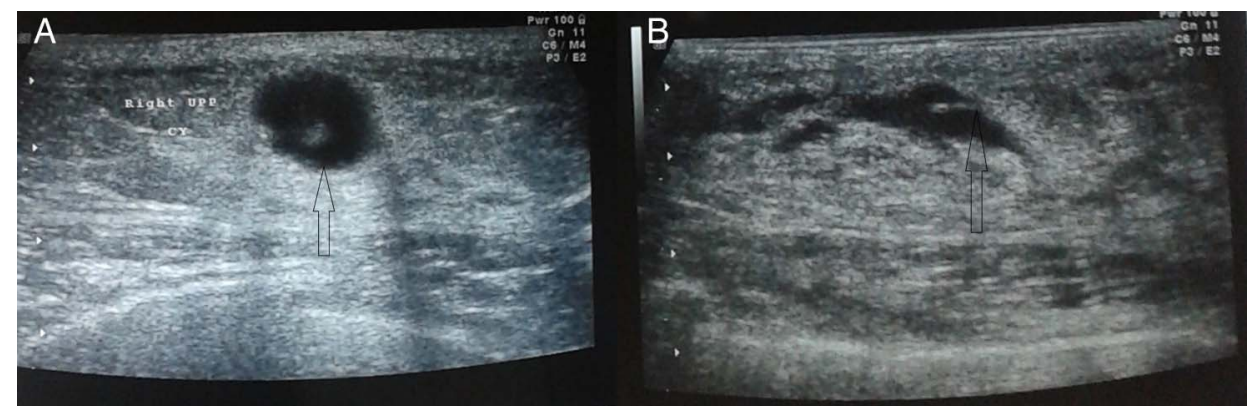

Figure 2 ( $A$ and $B$ ) Ultrasonography of right breast with arrow showing a cystic lesion with tongue-shaped projection with calcification inside it. 
Copyright 2015 BMJ Publishing Group. All rights reserved. For permission to reuse any of this content visit http://group.bmj.com/group/rights-licensing/permissions.

BMJ Case Report Fellows may re-use this article for personal use and teaching without any further permission.

Become a Fellow of BMJ Case Reports today and you can:

- Submit as many cases as you like

- Enjoy fast sympathetic peer review and rapid publication of accepted articles

- Access all the published articles

- Re-use any of the published material for personal use and teaching without further permission

For information on Institutional Fellowships contact consortiasales@bmjgroup.com

Visit casereports.bmj.com for more articles like this and to become a Fellow 